\title{
sciendo
}

DOI: 10.2478/orga-2020-0013

\section{The CSR Perception of Front- line Employees of Luxury Fashion Businesses}

\author{
Robert K. MACGREGOR ${ }^{1}$, Włodzimierz SROKA² \& Radka MACGREGOR PELIKÁNOVÁ ${ }^{1}$
}

\author{
${ }^{1}$ Metropolitan University Prague, Prague, Czech Republic, robertkmacgregor@yahoo.com \& \\ radkamacgregor@yahoo.com \\ ${ }^{2}$ WSB University, Dąbrowa Górnicza, Poland \& North West University, Potchefstroom, South Africa, \\ wsroka@wsb.edu.pl
}

Background and Purpose: The sustainability projected into Corporate Social Responsibility (CSR) is pivotal for luxury fashion businesses and they heavily refer to it. However, do their front-line employees follow this trend? To achieve an effective and efficient CSR, the front-line employees have to share the CSR perception advanced by their businesses. The main objective of the study is to discover, critically assess and compare the CSR perception of the front-line employees of the top luxury fashion industry businesses located in Prague, Czech Republic.

Design/Methodology/Approach: An investigative case study of the CSR approach of such employees of all ten top luxury fashion businesses in Prague is performed while using a holistic Meta-Analysis, a manual Delphi method and three rounds of interviews, along with mystery shopping techniques.

Results: The heterogenous conglomerate of data reveals: (i) problematic awareness of these employees, (ii) their ignorance of the legal setting, (iii) an imbalance and preferential focus, along with ignorance of certain CSR categories, (iv) direct and indirect contradictions and (v) a preoccupation with the fur issue.

Conclusions: This alarming inconsistencies and ambiguity have strong implications for both science and practice, they call for more studies, a deeper understanding of causes and a prompt correction in order to make the CSR perception of these important inside stakeholders be in line with expectations.

Keywords: Corporate Social Responsibility (CSR), EU law, Luxury fashion, Sustainability.

\section{Introduction}

The concept of sustainability emerged in the context of the economic globalization, dominated by more productivity, as well as social and ecological damage (Schüz, 2012). It reflects the value judgments about justice in the distribution and use of resources and rests on three pillars: economic (profit), environmental (planet) and social (people) dimension's continuity (MacGregor Pelikánová, 2019a). The leading force behind this newly launched trend were the United Nations (UN) which issued two milestone doc- uments: (i) the Report of the World Commission on Environment and Development; Report: Our Common Future prepared by the Brundtland Commission, published as the UN Annex to document A/42/427 in 1987 ("Brundtland Report 1987") and (ii) the Resolution made during a historic UN Summit in September 2015 and entitled Transforming our world: the 2030 Agenda for Sustainable development ("UN Agenda 2030"), which brought with it the 17 Sustainable Development Goals ("SDGs") and 169 associated targets. These two documents are the outcome of International Law and are not per se enforceable vis-à-

Received: 5th May 2020; revised: 28th June 2020; accepted: 5th July 2020 
vis businesses (MacGregor Pelikánová, 2019a).

The initial focus on sustainability has been progressively paralleled by corporate responsibility concerns (MacGregor Pelikánová, 2019a). Indeed, the original distinction between (i) sustainability in the narrow sense, with rather systematic and visionary features and designed for soft law and self-regulation, and (ii) corporate responsibility, with rather normative and moral features and designed for national law regulation, have converged in Corporate Social Responsibility (“CSR") (Bansal \& Song, 2017).

For the EU and EU member states, sustainability in the large sense represents a current multi-stakeholder relationship of virtually all members of society and even the society itself. Although the resulting CSR is only partially covered by mandatory EU law provisions and national law provisions (MacGregor Pelikánová, 2019b), the CSR that came of this represents a transparent dialogue and interaction between businesses and other stakeholders which should be materialized, among others, by publicly available financial reporting and non-financial reporting, i.e. CSR reporting (MacGregor Pelikánová, R. \& MacGregor, 2017).

There are extensive studies about the (lack of) CSR and CSR reporting progress in the automotive (MacGregor Pelikánová, 2019a), food (Haski-Leventhal, 2018), agricultural (Vveinhardt et al, 2019) and other industries (Sroka \& Szántó, 2018).

Sustainability is a central challenge of the fashion industry (Cerchia \& Piccolo, 2019). For luxury fashion businesses, the key values and competitive advantage determinants are linked to their luxury brands protected as trademarks (MacGregor Pelikánová \& MacGregor, 2019) and other Intellectual Property („IP“) assets (MacGregor Pelikánová, 2019c). Such brands represent scarcity, exclusivity and overflowing resources pointed to the top goals and priorities, such as CSR. They perfectly match the concept of a competitive advantage with a competitive target while engaging in ,capturing the core and broadening without diluting" (Moon et al, 2014). So, they desperately need to come across as standing up for CSR and as able to afford CSR, at least based on the expectations of their customers (Olšanová et al., 2018) and their potential investors (Morgan Stanley, 2017). Consequently, their commitment to CSR needs to be effectively and efficiently conveyed on all levels, including the bottom. However, what is the reality? How do front-line employees of luxury fashion businesses perceive CSR? Does their perception of the CSR match the indicated expectations of luxury fashion customers and investors?

This logically leads to the need to perform a deep micro-case study about the CSR perception of these inside stakeholders - front-line employees. Consequently, the main objective is to discover, critically assess and compare the CSR perception of the front-line employees of the top luxury fashion industry businesses in Prague. In order to address this pioneering objective, after the Liter- ature and Legislative Review (2.), Data and Methods (3.) needs to be discussed and this should be followed up by an engagement with explicit and implied CSR statements collected through the pioneering micro-case study performed in Pařižská regarding top luxury fashion businesses. Thus, Research findings and Discussion address interviews (4.1.), the observations gained via mystery shopping techniques (4.2.) and the comparison of the implied information (4.3.). The presented data and arguments culminate in the Conclusion (5.) which points to an unbalanced CSR perception of these internal stakeholders and a fragmentation that ultimately has a negative impact for society. Therefore, the reasons for this heterogeneity need to be understood and overcome.

\section{Literature and Legislative Review}

Both the concept of sustainability and CSR have grown with globalization, and the apparently unrestricted growth in the power of corporations has led to the proposition that global companies, as powerful economic, social and political actors, must increasingly be brought within the law's domain (Bunn, 2004). CSR is about the all-encompassing responsibility towards society, i.e. addressing all three sustainability pillars (Olšanová et al, 2018). CSR principles are a demonstration of moral obligations of the given business towards the entire society and this goes way beyond the mere concept of profit maximization. CSR emerged originally rather as an "ethical responsibility" than a "legal liability" and represented virtue ethics, utilitarian ethics, and deontological ethics (Schüz, 2012). Responsibility, as such, has Latin roots, see "respondere", and means that someone has to answer for the effects caused by him to an authority and this authority evaluates its damages (Schüz, 2012). If this regime is incorporated into the legal system and this authority is a judge, we deal with a special type of responsibility called 'liability'.

States have demonstrated various approaches to sustainability and accordingly have "delegated" some CSR tasks and duties to stakeholders, including businesses (MacGregor Pelikánová, 2019a). Therefore, CSR goes through a process of progression from none, to an over facultative one, to a mandatory regime (MacGregor Pelikánová, 2019a). Currently, CSR consists of many types of social responsibility: economic, legal, ethical, etc. (Sroka \& Szántó, 2018), i.e. it is a set of duties to adhere to in a certain manner because it is either morally or legally right or at least expected (MacGregor Pelikánová, 2019a). Herein, the movement from the soft sphere of ethics to the hard sphere of law with regard to what is to be, depends upon the jurisdiction.

The EU motto is "united in diversity" and the underlying idea is "Europe can succeed if it acts collectively, as a Union", especially regarding CSR, which is a dialogue and interaction between businesses, corporations and their 
stakeholders (MacGregor Pelikánová, 2017) that enjoys full EU endorsement via policy support (Šebestová et al, 2018). The primary EU law, especially the Treaty on the Functioning of the EU ("TFEU") underlines the social and environmental dimensions (Polcyn et al, 2019), along with the economic dimension of life (MacGregor Pelikánová \& MacGregor, 2018). Secondary sources, such as Regulations and Directives, and supplementary sources, must be in-compliance with primary sources, while carrying on strategic priorities (Piekarczyk, 2016). Regarding CSR, they include predominantly general and special Directives (MacGregor \& MacGregor Pelikánová, 2019), such as Directive 2013/34/EU of 26 June 2013 on annual financial statements and consolidated financial statements, as well as Directive (EU) 2017/1132 of 14 June 2017 relating to certain aspects of company law. EU and EU law priorities, targets and flagship initiatives are intra-related and arguably develop technological potentials (Balcerzak, 2016), recognize the $R \& D$ and IP impact on competitiveness (Marčeta \& Bojnec, 2020), the awareness and commitment with respect to CSR (MacGregor Pelikánová, 2018) and ephemeral philosophical-economical categories of ethics and fairness (Sroka \& Lörinczy, 2015). However, the ultimate choice remains up to European businesses, in how much they would go for CSR and report about it. They do not exhibit a unified trend, i.e. for some, their commitment towards sustainability via CSR is a mere imposed duty and a negative burden, while for other businesses, CSR is a vehicle for improvement in all three spheres of sustainability (economic, environmental and social) and an instrument to improve their own financial performance (Rodriguez-Fernandez, 2016).

Arguably, in the 21 st century EU, business ethics is regarded as a significant factor influencing the success and profits of modern businesses (Sroka \& Lörinczy, 2015). The related CSR represents the recognition of shared value policies and principles and aims at "a more sophisticated from of capitalism" (Porter \& Kramer, 2011). Consequently, if a business wants to be perceived as reliable and attract not only customers, but as well, employees, business partners and investors, it should demonstrate a high level of institutionalization of sustainable and ethical principles and practices (Sroka \& Szántó, 2018) and engage in a proper communication of the same externally and internally (Szanto, 2018). These arguments are covered by the stakeholder theory that proposes that the business engagement with CSR implies (at least indirectly) value creation through improvement of the business's reputation (Gallardo-Vázquez et al, 2019) and branding (Osei-Tutu, 2019) and ultimately an increase in market share (Ting et al, 2019) and enhanced financial performance (Rowley \& Berman, 2000). The originally simplistic CSR, thus, becomes strategic CSR and the evolution phases are: CSR cultural reluctance, CSR cultural grasp and CSR cultural embedment (Olšanová et al, 2018).

However, there are also some opponents of the overly positive CSR perception in the EU (Chwistecka-Dudek, 2016). They refer to traditional theories, are more sceptical, point to limitations due to possible agency conflicts between managers, shareholders, environmental activists, etc., and underline that resource allocation due to CSR, especially for social goals, may add to the costs, and, consequently, prevent profit maximization (Friedman, 2007). Pursuant to this, businesses should not automatically jump to the conclusion that more CSR and more CSR reporting must lead to an ultimate and global success. Several studies documented the negative impact of CSR activities and spending by indicating that CSR practices can generate unnecessary costs, cripple financial results (Barnett, 2007) and thus undermine competitive advantage (Scherer \& Palazzo, 2011).

Regardless of all these discourses, all modern businesses need to reconcile the profitability, growth and social relationships, i.e. CSR cannot be totally avoided and, according to the prevailing opinion stream, positively impacts financial performance (Ting et al, 2019). Each and every business in the EU must make a choice and implement it consistently.

The sphere of the luxury fashion industry is well suited to be a prima facia great platform for a CSR engagement by all stakeholders. The term "luxus" has a double meaning: it positively connotes such concepts as beauty, prestige, and power, but also implies excessive and ostentatious displays of wealth (Kapferer, 2012). The fashion luxury industry was traditionally linked to the allure of a limited access, heritage, sophistication, high desirability, excellent quality, high price and the extraordinary (Olšanová et al, 2018). It has also been associated with concepts like excessive consumerism, extremely high costs, elitism, opulence or guilty pleasures (Deloitte, 2019). However, recently it seems that two new luxury fashion customer groups have appeared - the HENRYs (High-Earners-Not-Rich-Yet) and youngsters (Millennials and Gen Z) (Deloitte, 2019; Dabija et al, 2019). Customers from these two groups, and perhaps even other customers, check online CSR reports, as well as the CSR direct manifestation in these shops, and they search for demonstrations of "their" ethical and moral values. Naturally, only motivated and committed internal stakeholders can extend these values and lead to satisfied business partners and customers.

In today's EU, luxury fashion businesses opted for a strong CSR commitment and their owners' and top-management statements explicitly confirm a developed proCSR perception while addressing the mentioned expected values (Olšanová et al, 2018). Obviously, this pro-CSR strategy can be effective and efficient only if all internal stakeholders share it (Bunn, 2004). Properly tailored CSR practices can be cost effective (Osei-Tutu, 2019) only if internal stakeholders know about them, agree upon them and consistently inform others about them in a unified manner (Ikram et al, 2019). Since the sustainability drive is strongly culturally influenced, it is pivotal to reconcile the 
CSR perception by all internal stakeholders (Burksiene et al, 2018) regarding CSR categories. These categories are indirectly implied by the EU law on non-financial (CSR) reporting, especially Directive 2013/34/EU as updated, and have been recently established by academia (MacGregor Pelikánová, 2019a):

- environment protection (MacGregor Pelikánová, 2019a),

- $\quad$ employee matters (Dvouletý, 2017),

- social matters and community concerns (Mallin, 2018),

- respect for human rights (Osei-Tutu, 2019),

- anti-corruption and bribery matters (Sroka \& Szántó, 2018) and

- R\&D activities (Marčeta \& Bojnec, 2020).

However, there is a lack of studies about the reality and dynamics of these internal CSR perceptions. Namely, there are basically no studies about the CSR perception of frontline employees of luxury fashion businesses. This situation is amazing because these businesses rely much more on face-to-face interaction than do anonymous online sales, and their ambassadors vis-à-vis customers - their front-line employees - play a critical role with respect to the consistency and ultimately effectiveness and efficiency of their pro-CSR perception.

\section{Data and Methods}

The data and methods used in this paper are determined by the main objective, which is, via an investigation, to discover, critically assess, and compare the CSR perception of front-line employees of the top luxury fashion industry businesses in the Czech Republic. Specifically, it is about obtaining direct and indirect information about CSR perceptions conveyed by the employees facing customers in Pařížská street in Prague. This case study is based upon a research of predominantly primary data and the processing of such by methods that are both critical and comparative (Yin, 2008). It allows for retaining the holistic and meaningful characteristics of real-life events (Yin, 2008). The parameters were obvious, i.e. the case study included all businesses located in Prague's "Luxury Fashion Street", AKA "Prague's 5th Avenue", which sell luxury clothing brands and specifically, leather handbags. The criterion of leather handbags is used because they are indicators and/ or the "engine that drives luxury brands today" (Han et al, 2010). The primary data about the statements of the employees was directly obtained by interviews and indirectly by mystery shopping techniques. Each interview had two parts - structured (posing four questions) and unstructured (invitation for providing further information about products, brand and CSR). Namely, each of these front-line employees was asked to show a woman's leather bag size
A4 and to explain (i) the product's material and functional advantages, (ii) its brand advantages, (iii) business relation to CSR and (iv) the employee's knowledge about CSR regulations. They were then induced to provide any other relevant CSR information. Mystery shopping techniques, i.e. mystery consumer methods and techniques (Osterweil, 2012), included observations of CSR positive and negative indices, such as social (un)friendliness (co-operation, competition and arrogancy between employees and vis-àvis customers), environment (un)friendliness of the shop setting (used materials, light fixtures, etc.) and packaging material (recycling, etc.), concept design and human interaction. Table 1 lists those businesses examined by the case study, which are all businesses meeting the set requirements (luxury fashion - leather bags), i.e. no business was omitted and hence the list is exhaustive.

The authors have been consistently litigating for the use of the qualitative analysis (Vourvachis \& Woodward, 2015) and the holistic Delphi method for CSR studies (MacGregor Pelikánová, 2019a). Consequently, even this case study builds upon a rather qualitative holistic manual Delphi method (Okoli \& Pawlowski, 2004) with rankings done by three experts with economics and law backgrounds and CSR knowledge (due to the GDPR and privacy issues, only the initials of these three experts are provided: EDC, LM, ZUP) and in addition all of them have already purchased these types of luxury products and were open to purchase them again, i.e. they were "real". The ranking was done by each of them independently with the same weight. They did both interviews and mystery shopping observations and classified the yielded information about each of the six CSR categories with $(+)$ or $(++)$ or $(+++)$. Information implying ignorance of, or a disregard for CSR got (0), while information implying a general and weak CSR perception got $(+)$, deeper and more specific CSR information netted $(++)$ and genuine and excellent CSR information got $(+++)$. These interviews and mystery shopping observations were done in three rounds and, pursuant to the holistic manual Delphi method, generated ranking and notes whereby these three experts compared, discussed and readjusted. Hence, each of these top 10 luxury fashion businesses in Pařížská was visited three times in December 2019 (each time by a different expert of these three), i.e. in total - 30 visits. During their visits, the mystery shoppers performed the above described interviews with both a structured (4 questions) and a non-structured part to extract direct indices about the CSR perceptions of front-line employees, and mystery shopping observation to extract indirect indices. Involved front-line employees shared slightly different cultural backgrounds (Czech, Slovak, Russian), which could originally impact their sustainability and CSR perceptions (Burksiene et al., 2018). Since these employees provided the interviewing experts with documents (e.g. marketing leaflets shown and discussed by employees), qualitative content text analysis (Kuckartz, 
Table 1: Case Study - Six luxury fashion business groups and their ten top businesses

\begin{tabular}{|c|c|c|c|}
\hline Group & Business & Origin & $\begin{array}{c}\text { Revenue in 2018 } \\
\text { (bil EUR) }\end{array}$ \\
\hline LVMH & Louis Vuitton & 1854, Paris & 46.8 \\
\hline LVMH & Christian Dior & 1945, Paris & 46.8 \\
\hline LVMH & Fendi & 1925, Rome & 46.8 \\
\hline LVMH & Bulgari & 1884, Rome & 46.8 \\
\hline Kering & Gucci & 1921, Florence & 4.65 \\
\hline Kering & Bottega Veneta & 1966, Vicenza & 4.65 \\
\hline Prada & Prada & 1913, Milan & 3.14 \\
\hline Dolce Gabanna & Dolce Gabanna & 1982, Milan & 1.29 \\
\hline Tod's & Tod's & 1920, St.Elpid. & 0.96 \\
\hline Furla & Furla & 1927, Bologna & 0.58 \\
\hline
\end{tabular}

Source: Prepared by the authors and based on their field searches performed in December 2019.

2014) was marginally used as well (Krippendorff, 2013).

This framework and employment of both intrinsic and extrinsic evidence and direct and indirect indices facilitates a holistic processing that reveals possible trends. Its benefits are maximized by the parallel use of Meta-Analysis, which is an analysis of analyses (Schmidt \& Hunter, 2014), i.e. a quasi-statistical analysis of a large collection of results from individual studies with the goal of integrating their findings (Glass, 1976). The use of three rounds for the Delphi ranking with adjustments, along with the Meta-Analysis of additional information, along with Socratic questioning (Areeda, 1996), reduces the inherent subjectivity and boosts the academic robustness of this case study.

\section{Research findings and Discussion}

Often, the setting of the law and appropriate regimes is one thing, while their application is quite another matter entirely. A proper and committed perception of the CSR is a pre-requirement for the EU's expected approach to CSR by a critical group of stakeholders shaping the CSR of the entire business - the internal stakeholders of luxury fashion businesses. These ambassadors are either de iure representatives of these businesses, CEOs preparing, issuing and signing CSR reports or Codes of Ethics, or de facto representatives of these businesses - front-line employees facing the clientele on "5th Avenue", i.e. Pařížská street. It might be expected that luxury fashion businesses are (should be) aware about the importance of the mes- sage conveyed by these front-line employees and that they make sure to motivate these front-line employees to directly and indirectly promote the best information about the illustrious commitment for all six CSR categories of the given business. However, perhaps this is mere speculation. Therefore, it is quite legitimate, via investigations, to discover, critically assess and compare the approach of the front-line employees of the top luxury fashion industry businesses in Prague, both directly by interviews and indirectly by mystery shopping techniques. Hence, in December 2019, a repeated (3x) field search of all 10 luxury fashion businesses was performed, entailing both interviews and mystery shopping.

\subsection{Front-line employees' direct statements - interviews}

Each shop was visited 3x in December 2019 and an interview consisting of two parts, along with mystery shopping was performed. The information from these three sets of interviews was processed and re-adjusted by the Delphi method, is summarized in Table 2 and 3 and commented in a semi-anonymized manner while using codes instead of names of these luxury businesses.

Manifestly, direct statements during the first half of each interview of the front-line employees of these ten top luxury fashion businesses have not differed dramatically, while interesting trends across this special segment of industry could be observed. Basically, all employees covered 
Table 2: Employees' direct statements during the first half of interviews about CSR categories; businesses' names are replaced by codes

\begin{tabular}{|c|c|c|c|c|c|c|}
\hline & Environm. & Empl.Mat. & Social & HumRight & $\begin{array}{c}\text { An- } \\
\text { ti-Corr. }\end{array}$ & R\&D \\
\hline A & ++ & + & ++ & 0 & 0 & + \\
\hline B & ++ & + & ++ & 0 & 0 & ++ \\
\hline C & ++ & + & ++ & 0 & 0 & +++ \\
\hline D & ++ & ++ & ++ & 0 & 0 & +++ \\
\hline E & +++ & ++ & + & 0 & 0 & + \\
\hline F & ++ & ++ & + & 0 & 0 & 0 \\
\hline G & +++ & ++ & + & 0 & 0 & +++ \\
\hline H & ++ & ++ & + & 0 & 0 & + \\
\hline I & ++ & ++ & + & 0 & 0 & + \\
\hline J & + & + & + & 0 & 0 & + \\
\hline
\end{tabular}

Source: Prepared by the authors and based on their own searches and interrogations (interviews).

the environment, employee matters, social and R\&D categories, and totally skipped Human rights and Anti-corruption categories. However, the second part of the interviews proved to be very interesting and highly revealing and thusly allowed for the differentiation between the intensity of the CSR commitment regarding the four mentioned categories.

A clear "leader" among CSR categories was the environment category and basically each and every employee addressed it extensively and in a different, original manner. Some employees underlined the tradition and animal welfare policies without going in much detail (A, B). Other employees provided more moderate environment statements oriented not to animal welfare, but they backed them strongly with facts (C, D). Certain employees seemed almost obsessed with animal welfare, energy saving and recycling (E, G). Finally, some employees provided rather weak information without any interest to speak further about it (F, I).

Next in line were employee matters and social categories, for which rather general statements were made with a reluctance to go into details. The biggest difference was within the R\&D category, regarding which some employees volunteered a lot of information $\mathrm{C}, \mathrm{D}$ ), a little information (A, B, E, I) or not any information (F). As stated above, no employee mentioned Human rights and anti-corruption categories.

Manifestly, the front-line employees either do not know about the CSR legal framework or their perception of it is incorrect. One half of the front-line employees in- terviewed totally failed this part, the other half demonstrated only some basic knowledge.

The second half of each interview allowed for a free flow of communication and for letting the employees volunteer information about CSR. The information from these three sets of interviews was processed and re-adjusted by applying the Delphi method, is summarized in Table 4 and commented in a semi-anonymized manner while using codes instead of names of these luxury businesses.

Manifestly, direct statements during the second half of each interview provided a more colourful picture, and the rather small differences became magnified. Some employees were reluctant to carry on the discussion (B), show patronage preferences, patronization and favouritism of certain clients over others (Vveinhardt \& Sroka, 2020), or even became confused and contradicted themselves (A) and ultimately even provided information against CSR.

From the six CSR categories, only four were mentioned and clearly the environment category with animal welfare took the lead. Well-informed employees pushed this issue, while underlining their concurrent opinion (E, $\mathrm{G}$ ), and poorly informed employees became confused (A). Some employees kept repeating the same information (I), while others admitted that they are not on the same page (F). Amazingly, some employees declined to carry on the discussion and left to speak to someone else (B). Employees from less animal-welfare oriented businesses gladly volunteered deep insightful information showing that the entire environment category is manipulated. Doubtless the 
Table 3: Employees' direct statements during the first half of interviews - awareness about international, regional and national laws on CSR

\begin{tabular}{|c|c|c|c|c|}
\hline & $\begin{array}{c}\text { International } \\
\text { law (SDG) }\end{array}$ & $\begin{array}{c}\text { Regional law } \\
\text { (EU reporting) }\end{array}$ & $\begin{array}{c}\text { Regional law (EU } \\
\text { restrictions) }\end{array}$ & $\begin{array}{c}\text { National law (CZ } \\
\text { law on CSR }\end{array}$ \\
\hline A & + & 0 & + & 0 \\
\hline B & + & 0 & + & 0 \\
\hline C & + & 0 & ++ & + \\
\hline D & ++ & 0 & ++ & + \\
\hline $\mathbf{E}$ & ++ & 0 & ++ & + \\
\hline F & ++ & 0 & 0 & 0 \\
\hline G & ++ & 0 & 0 & 0 \\
\hline H & 0 & 0 & 0 & 0 \\
\hline I & 0 & 0 & ++ & + \\
\hline J & 0 & 0 & + & + \\
\hline
\end{tabular}

Source: Prepared by the authors and based on their own searches and interrogations (interviews).

Table 4: Employees' direct statements during the second half of interviews (initiated by employees)

\begin{tabular}{|c|c|c|c|c|c|c|}
\hline & Environm. & Empl.Mat. & Social & HumRight & $\begin{array}{c}\text { An- } \\
\text { ti-Corr. }\end{array}$ & R\&D \\
\hline A & 0 & 0 & + & 0 & 0 & + \\
\hline B & 0 & + & + & 0 & 0 & ++ \\
\hline $\mathbf{C}$ & +++ & ++ & ++ & 0 & 0 & +++ \\
\hline $\mathbf{D}$ & ++ & ++ & ++ & 0 & 0 & +++ \\
\hline $\mathbf{E}$ & +++ & ++ & + & 0 & 0 & + \\
\hline $\mathbf{F}$ & + & + & + & 0 & 0 & 0 \\
\hline $\mathbf{G}$ & +++ & ++ & + & 0 & 0 & +++ \\
\hline $\mathbf{H}$ & ++ & ++ & + & 0 & 0 & + \\
\hline $\mathbf{I}$ & + & + & + & 0 & 0 & + \\
\hline $\mathbf{J}$ & + & + & + & 0 & 0 & + \\
\hline
\end{tabular}

Source: Prepared by the authors and based on their own searches and interrogations (interviews). 
most interesting revelation was the information that artificial fur done by $\mathrm{G}$ and $\mathrm{E}$ actually represents an environmental hazard because, unlike animal fur, it does not easily and naturally decompose.

The employees had very little to say about social and R\&D categories, but surprisingly mentioned some employment matters and became very clear that there is a big fluctuation among the employees from these businesses. Moreover, often the only way to get a job promotion is to "go next door", in other words, to take a job with another store in Pařížská. During the second part of the interviews, there often arose the issue of the working place dynamics, and it became obvious that a strict and rigid hierarchical approach prevails, and often junior employees are treated with a total lack of respect (G). Prima facia, it looked like promotion via merit and qualifications is not a core value (B) and employees oscillate between acting strictly, to being almost arrogant (B, I) and even down to a familiar approach more fitting for those working in a supermarket $(\mathrm{F})$.

Finally, during the second half of the interviews, the varying cultural and linguistic levels of the employees, as well as a general failure of effective employee training and education, became apparent. In sum, the first half of the interviews showed small differences that became magnified by the second half interviews and called for testing via mystery shopping techniques.

\subsection{Front-line employees' indirect statements - mystery shopping}

Since no indices were revealed regarding social matters, human rights, and anticorruption categories, only the remaining three CSR categories were examined by the mystery shopping observation and are presented in Table 5 . Namely, the CSR category of the environment was observed while focusing on the mimicry and facial-body language of front-line employees and their manner of touching and dealing with products. The CSR category employment matters was observed while focusing on the mutual interaction between front-line employees and their dress code. The CSR category R\&D was observed while focusing on the manner of product demonstrations, along with mimicry and facial-body language.

Table 5: Employees' indirect statements - mystery shopping revelations

\begin{tabular}{|c|c|c|c|}
\hline CSR Category & Environm. & Empl.Mat. & R\&D \\
\hline Criteria & $\begin{array}{c}\text { Mimicry + Material } \\
\text { touch }\end{array}$ & $\begin{array}{c}\text { Interaction + Dress- } \\
\text { ing }\end{array}$ & $\begin{array}{c}\text { Demonstrating + } \\
\text { Mimicry }\end{array}$ \\
\hline A & 0 & 0 & 0 \\
\hline B & + & 0 & 0 \\
\hline C & ++ & ++ & +++ \\
\hline D & ++ & ++ & +++ \\
\hline E & +++ & ++ & + \\
\hline F & + & + & +++ \\
\hline G & +++ & ++ & + \\
\hline I & + & + & + \\
\hline J & + & + & 0 \\
\hline K & + & + & + \\
\hline
\end{tabular}

Source: Prepared by the authors and based on their own searches and interrogations (interviews). 
Of all the tables, clearly the last one, Table 5 , is the most revealing and confirms that there is a big difference between these businesses, i.e. the CSR approach of their employees. Those initially disappointing are confirmed, and the mystery shopping techniques underline that these front-line employees made weak attempts to pretend to be committed CSR ambassadors (A, B) and demonstrate favouritism inclinations. These findings match recent studies in comparable settings and ultimately support their very correct conclusions (Vveinhardt \& Sroka, 2020).

Other front-line employees do not have such ambitions and ultimately appear much more convincing (F, H, I, J). The "winners" are either those employees who are quite environmentally aware (E, G) or employees deeply aware of traditions and concepts (C, D). With but small exaggeration, it can be stated that the split between the most CSR committed employees is done based on the preference: free fur v. fun fur.

Naturally, it would be remiss to neglect the presentation of these results coupled with short notes about the setting in which the employees operate, while referring to these ten businesses and their six groups.

LVHM comes across as a modern light shopping mall, AKA warehouse, without any privacy and where customers form lines, while with $\mathrm{B}$, the dark shop setting reflects the scandalous and perverse history of the B family and is matched with the arrogance of certain employees. $\mathrm{C}$ and D's shop settings, as well as employees, are dramatically different, they are nice, bright, and employ an individual approach; they treat customers with charm and friendliness, even with a nice touch of decent humour and know much more about the history and concept $(\mathrm{C}, \mathrm{D})$ than their colleagues about (A, B). Hence the LVMH group does not appear as overly consistent.

In contrast, the Kering group is very consistent and both the setting, as well as the employees stress animal welfare and other environmental issues (energy, recycling). It almost looks like the most critical issue at hand is to provide a wonderful life for the animals if their skin is soon to be used and there is an extreme feeling of guilt about their fate. Sadly, little attention is paid to IP and so the nice and committed, and rather humble, employees show "pro-environment" products, but creativity and sophistication are missing.

$\mathrm{G}$ is similar to the Kering group and its fur free status is obvious and demonstrated by its exhibit hall. Its employees are committed and have exceptionally deep knowledge. They are confident and respectful, even while speaking about their competition. Interestingly, they describe the competing B store as a fairy tale world (however, based on the author's experience, a visit to B can easily turn into a dark nightmare and a truly unhappy fairy tale, inappropriate for small children). They are enthusiastic about their substitutes and their pro-environment approach. The rain on this parade is provided by bits of information offered by $\mathrm{C}$ 's employees who informed us that $\mathrm{G}$ substitutes are extremely environmentally unfriendly in the long term.

$\mathrm{H}, \mathrm{I}$ and $\mathrm{J}$ appear much more modest, their shops do not convey a strong luxury impression and their employees follow this rather minimalist, honest approach.

\subsection{Comparison and discussion}

There is a clear gap between those ready to make grandiose proclamations and possibly lacking integrity and those who are more modest. Further, the obtained results have to be appreciated in the light of available recognized international indexing tools. According to the CSR HUB Sustainability Management Tools CSR/ESG ranking, the leaders are Gucci (96\%), Louis Vuitton (92\%), Christian Dior (89\%), while the CSR underperformers should be Tod's (28\%), Fendi (22\%) (CSR Hub, 2019). Manifestly, CSR Hub works more with quantitative than qualitative indicators and so matches up well with the key word's frequency in CSR reports and Codes of Ethics and much less with Delphi indicators and employee statements. Despite all possible objections, the CSRHub basically confirms all the above-mentioned common elements and stresses internal differences between businesses in the same group. Namely, within LVHM, some employees $(\mathrm{A}, \mathrm{B})$ have dramatically different approaches to CSR than other employees $(C, D)$. Further, this confirms the importance of the individual background and culture for the sustainability and CSR perceptions (Burksiene et al, 2018).

The performed pioneering case study managed to bring together direct and indirect statements implied by interviews, as well as field observations yielded via mystery shopping techniques. The holistic Meta-Analysis of this rather heterogenous conglomerate of data reveals five highly significant aspects regarding the CSR perception of these front-line employees: (i) their problematic awareness, (ii) their ignorance of the legal setting, (iii) their imbalanced and preferential focus along with ignorance of certain CSR categories, (iv) their direct and indirect contradictions and (v) their almost obsessive preoccupation with the fur issue - fun fur (using fur is fun and indispensable) v. free fur (using fur is evil and wasteful).

Firstly, the awareness of these front-line employees about CSR is dramatically different and it appears that many top luxury fashion businesses totally omit the proper selection and training of their employees and contribute to the massive job fluctuation. It is amazing that these differences are even between employees from the same group (LVMH - A, B v. C, D).

Secondly, front-line employees know very little about CSR regulations and are confused about the mandatory and facultative positive law provisions. They do not appreciate the differences between jurisdictions and confuse moral and legal obligations. For example, only a few front- 
line employees understood the mandatory setting for the sale and use of fur products. Generally, they are inclined to believe that environmental aspects are compulsory, while social and other CSR categories are beyond the reach of the law, including reporting. Sadly, the SDGs and international law dimension is completely outside their awareness.

Thirdly, the prevailing focus is on the environmental and employee matters of CSR categories, with an undertone of interest for brand history and for IP. This is totally in contrast with the conventional understanding of this industry, which is basically built by selected family fame and excellence. Further, the SDGs of the UN are obviously not major concerns of the front-line employees of these businesses.

Fourthly, even if the front-line employees should be convincing and consistent ambassadors of these luxury leaders, they often prove to be poorly informed, not committed and not professional enough to avoid contradicting themselves, providing poor customer service and denying the CSR.

Fifthly, a top CSR concern of almost of all these employees is the burning issue of what materials are used and how they are obtained. Therefore, after general CSR proclamations, there comes a fast spiel whether is it evil to use animal fur or not. Considering the current global issues (drought, warming, disappearing icebergs and tropical forests, ozone-hole, COVID, etc.), it is rather surprising that front-line employees totally depart from SDGs and even from the top hallmarks of their employers-businesses. With all due respect to animal welfare, perhaps this should not be a top CSR concern, neither should it definitely take priority over SDGs. This luxury slow fashion should return to core values and distinguish itself from the fast fashion (Niinimäki et al, 2020).

These five aspects are both surprising and not matching with the expected and desired CSR image of top brands, including leading luxury fashion businesses (Adamska, 2020). Indeed, the case study points to a myriad of flaws requiring prompt correction, provided that the CSR approach of luxury fashion businesses is to be genuine, effective, and efficient. It confirms the prior finding about the critical importance of external, as well as internal communications regarding the CSR, especially in the multi-national settings (Szanto, 2018) as well as cross-sectorial setting (Van Tulder et al, 2016). Exactly that is typical for the luxury fashion industry. However, it is not only about the cure, it is as well about prevention and so the question 'how' should be paralleled with the question 'why'. Indeed, the proper understanding of the causes of the current deplorable status is indispensable for achieving a correction and for bringing all stakeholders on board in order to make the concept of sustainability and SDGs real and worthy of the efforts of all concerned (van Tulder \& Keen, 2018). Science should explore this discrepancy, and practice should promptly take action by engaging in communications with their employees.

\section{Conclusions}

The EU wants to engage businesses with the sustainability issue and attempts to boost their CSR directly by harmonizing the reporting and indirectly pushing businesses to be transparent regarding their CSR. In addition, the importance of sustainability, business ethics and CSR has been growing and this trend continues. Luxury fashion businesses are aware of it and declare their commitment to CSR in a manner definitely exceeding the strict legal minimum demanded by the EU law. All six CSR categories as implied by the EU law, and related practices appear to be relevant for these businesses.

Despite the rather small sample, the performed case study brings forth valuable information about ALL top luxury fashion businesses in the Czech Republic, and, considering their international nature, perhaps even about almost ALL top luxury fashion businesses in the EU. Hence, the main objective was met by investigative discovery, critically assessing and comparing the approach of the front-line employees of these top luxury fashion industry businesses in Prague.

The mentioned set of valuable, truly pioneering and, for the future, research calling aspects, entail especially (i) problematic awareness, (ii) their ignorance of the legal setting, (iii) imbalances and preferential focus, along with ignorance of certain CSR categories, (iv) direct and indirect contradictions and (v) a preoccupation with the fur issue. This has strong implications for both science and practice.

Indeed, the case study reveals interesting information, trends, patterns and even discrepancies and fragmentation. The CSR approach of those individuals voicing CSR policies for top luxury fashion businesses has very little in common, or at least similar, to the objectives set globally by the UN, regionally by EU and nationally by EU member states as vocalized by their statements and materialized by their actions. Lost in translation? Do we have here just individual failures or systemic issues? Science and practice should work together to understand this and to find reasons for it and to identify instruments for improvement.

The CSR approaches of front-line employees of luxury fashion businesses are trailing much behind expectations, at least the expectations of CSR global, regional, and national policy makers. This is very alarming, especially considering the need of the multi-stakeholder approach. Indeed, this alarming inconsistency and ambiguity calls for more studies, deeper understandings of causes and prompt corrections in order to bring the CSR perception of these important inside stakeholder in line with expectations.

There are several managerial contributions of our study. Firstly, it presents the results of a case study anal- 
ysis related to the manager's attitudes to marketing and innovations in luxury fashion industry in relation to the CSR concept, thus delivering findings to the current debate on the topic. Secondly, such research is rather rare and the CSR concept is analysed mostly in relation to other aspects, such as the impact on a company's performance and its image, relationships between employee, mobbing or nepotism. Given this fact, this aspect is a significant added value of the study. Thirdly, the results achieved may be used for the formulation of the research hypotheses in further surveys.

Of course, our study is not free of limitations, the first of which is the analysis of only one sector existing in one country. The research could and should be expanded while considering different internal and external stakeholders (e.g. different type of employees, agents, consumers, etc.), different EU member states and/or different sectors which are able and expected to go actively for CSR (e.g. financial services sector, pharmaceutical sector, etc.) and different time lines (statements in different years). Such longitudinal, comparative and cross-sector studies could yield extremely relevant and pioneering conclusions and recommendations. Another limitation of our current study is the method used. We employed the case study analysis and a quantitative approach might be used in future research to explore the in-depth nature of the phenomenon. Indeed, the methodology adjustment is necessary if the above suggested and highly ambitious comparison is to be developed. Despite these limitations, we strongly believe that this study presents the real situation with regard to marketing and innovations in the luxury fashion industry and their connections to the CSR concept.

\section{Acknowledgement}

This paper is the result of Metropolitan University Prague's research project no. 74-02 "Territorial Studies, Economics, International Relations" (2020) based on a grant from the Institutional Fund for the Long-term Strategic Development of Research Organisations.

The project was funded within the auspices of the programme of the Minister of Science and Higher Education entitled "Regional Initiative of Excellence" in 2019-2022, project number 018/RID/2018/19; amount of funding: PLN 10,788,423.16.

\section{Literature}

Adamska, M. (2020). Practical Application of Forms and Tools of Marketing Communication in the SME Sector. E\&M Economics and Management, 23(2), 193209. http://doi.org/10.15240/tul/001/2020-2-013

Areeda, Ph.E. (1996). The Socratic method. Harvard Law Review, 109(5), 911-922

Balcerzak, A.P. (2016). Technological Potential of European Economy. Proposition of Measurement with Application of Multiple Criteria Decision Analysis. Montenegrin Journal of Economics, 12(3), 7-17. http://doi. org/10.14254/18005845.2016/12-3/1

Bansal, P. \& Song, H.C. (2017). Similar, but not the Same: Differentiating Corporate Sustainability from Corporate Responsibility. Academy of Management Annals, 11(1), 105-149. http://doi.org/10.5465/annals.2015.0095

Bunn, I.D. (2004). Global Advocacy for Corporate Accountability: Transatlantic Perspectives from the NGO Community. American University International Law Review, 19(6), 1265-1306.

Burksiene, V.; Dvorak, J. \& Burbulyte-Tsiskarsishvili, G. (2018). Sustainability and Sustainability Marketing in Competing for the Title of European Capital of Culture. Organizacija, 15(1), 66-78, http://doi.org/10.2478/ Orga-2018-0005

Cerchia, R.E. \& Piccolo, K. (2019). The Ethical Consumer and Codes of Ethics in the Fashion Industry. Laws, 8, 23. http://doi.org/10.3390/laws8040023

Chwistecka-Dudek, H. (2016). Corporate Social Responsibility: supporters vs. opponents of the concept. Forum Scientiae Oeconomia, 4(4), 171-179.

CSRHub (2019). CSRHub available at https://www.csrhub.com/

Dabija, D.C.; Bejan, B. \& Dinu, V. (2019). How Sustainability Oriented is Generation $\mathrm{Z}$ in Retail? A Literature Review. Transformations in Business \& Economics, 18(2), 150-155.

Deloitte (2019). Global Powers of Luxury Goods 2019. Bridging the gap between the old and the new. Retrieved January 5, 2020, from https://www2.deloitte. $\mathrm{com} /$ content/dam/Deloitte/es/Documents/bienes-comsumo-distribucion-hosteleria/Deloitte-ES-consumer-industry-global-powers-luxury-goods-2019.pdf

Dvouletý, O. (2017). What is the Relationship between Entrepreneurship and Unemployment in Visegrad Countries? Central European Business Review, 6(2), 42-53. http://doi.org/10.18267/j.cebr.179

Friedman, M. (2007). The Social Responsibility of business is to Increase its Profits. In: Zimmerli W.C., Holzinger M., Richter K. (eds) Corporate Ethics and Corporate Governance. Springer, Berlin, Heidelberg, 173-178. http://doi.org/10.1007

Gallardo-Vázquez, D.; Valdez, L. \& Castuera-Diáz, A.M. (2019). Corporate Social Responsibility as an Antecedent of innovation, Reputation, and Competitiveness 
Success: A Multiple Mediation Analysis. Sustainability, 11(20), 5614. http://doi.org/10.3390/su11205614

Glass, G.V. (1976). Primary, secondary, and meta-analysis of research. Educational Researcher, 5 (10), 3-8.

Han, Y.J.; Nunes, J.C. \& Dreze, X. (2010). Signalling Status with Luxury Goods: The Role of Brand Prominence. Journal of Marketing, 74(4), 15-30.

Haski-Leventhal, D. (2018). Strategic Corporate Social Responsibility. Los Angeles: SAGE Publication.

Ikram, A.; Li, Z.F. \& Minor, D. (2019). CSR-contingent executive compensation contracts. Journal of Banking \& Finance. https://doi.org/10.1016/j.jbankfin.2019.105655

Kapferer, J.N. (2012). The luxury strategy: break the rules of marketing to build luxury brands. Kogan Page Publishers, London.

Krippendorff, K. (2013). Content Analysis: An Introduction to its Methodology. Los Angeles, CA: Sage.

Kuckartz, U. (2014). Qualitative Text Analysis - A Guide to Methods, Practice and Using Software. $1^{\text {st }}$ Edition. Sage Publications Ltd.

MacGregor, R.K. \& MacGregor Pelikánová, R. (2019). Shareholder Engagement for Corporate Governance in the Light of the Harmonization and Transposition. International Journal of Economics and Business Administration, VII(4), 22-34.

MacGregor Pelikánová, R. (2017). European Myriad of Approaches to Parasitic Commercial Practices. Oeconomia Copernicana, 8(2), 167-180. http://doi. org/10.24136/oc.v8i2.11

MacGregor Pelikánová, R. (2018). The nebulous effectiveness, efficiency and fairness of the European e-Justice Portal vis-à-vis Corporate Social Responsibility. Progress in Economic Sciences, 5, 127-141. http://doi. org/10.14595/PES/05/008

MacGregor Pelikánová, R. (2019a). Corporate Social Responsibility Information in Annual Reports in the EU - Czech Case Study. Sustainability, 11, 237. http://doi. org/10.3390/su11010237

MacGregor Pelikánová, R. (2019b). Harmonization of the protection against misleading commercial practices: ongoing divergences in Central European countries. Oeconomia Copernicana, 10(2), 239-252. http://doi. org/10.24136/oc.2019.012

MacGregor Pelikánová, R. (2019c). R\&D expenditure and innovation in the EU and selected member states. Journal of Entrepreneurship, Management and Innovation 15(1), 13-33. http://doi.org/10.7341/20191511

MacGregor Pelikánová, R. \& MacGregor, R. (2017). European e-Justice Portal - Reality of Electronic OneStop-Shop for Publication of Financial Statements in the EU. In: Jindřichovská, I.; Kubíčková, D. Conference: 5th International Scientific Conference on IFRS - Global Rules and Local Use. Anglo-American University.

MacGregor Pelikánová, R. \& MacGregor, R. (2018). Corporate Social Responsibility e-Reporting as a tool for (Un)fair competition in the EU. In Löster, T.; Pavelka,
T. (Eds.). Conference Proceedings. The $12^{\text {th }}$ International Days of Statistics and Economics. University of Economics, Prague.

MacGregor Pelikánová, R. \& MacGregor, R. (2019). The Impact of the New EU Trademark Regime on Entrepreneurial Competitiveness. Forum Scientiae Oeconomia, 7(2), 59-70. http://doi.org/10.23762/FSO_VOL7_ $\mathrm{NO} 24$

Marčeta, M. \& Bojnec, Š. (2020). Drivers of Global Competitiveness in the European Union Countries in 2014 and 2017. Organizacija, 53(1), 37-52. http://doi. org/10.2478/orga-2020-0003

Moon, H.-C. et al. (2014). Extending Porter's generic strategies: from three to eight. European Journal of International Management, 8(2), 205-225. http://doi. org/10.1504/EJIM.2014.059583

Morgan Stanley (2017). Millennials Drive Growth in Sustainable Investing. Morgan Stanley. Retrieved January 5, 2020 from https://www.morganstanley.com/ideas/ sustainable-socially-responsible-investing-millennials-drive-growth

Niinimäki, K., Peters, G., Dahlbo, H., Perry, P., Rissanen, T., Gwilt, A. (2020). The Environmental Price of Fast Fashion. Nature Reviews Earth \& Environment, 1:189200. http://doi.org/10.1038/s43017-020-0039-9

Okoli, Ch. \& Pawlowski, S.D. (2004). The Delphi method as a research tool: an example, design considerations and applications. Information \& Management, 42(1), 15-29. http://doi.org/10.1016/j.im.2003.11.002

Olšanová, K.; Gook, G, \& Zlatić, M. (2018). Influence of Luxury Companies' Corporate Social Responsibility Activities on Consumer Purchase Intention: Development of Theoretical Framework. Central European Business Review, 7(3), 1-25.

Osei-Tutu, J.J. (2019). Socially Responsible Corporate IP. FIU Legal Studies Research Paper Series. Research Paper No. 19-01.

Osterweil, W. (June 4, 2012). The Secret Shopper. The New Enquiry. Retrieved January 10, 2020 from https://thenewinquiry.com/the-secret-shopper

Piekarczyk, A. (2016). Contemporary organization and a perspective on integration and development. Oeconomia Copernicana, 7(3), 467-483. http://doi. org/10.12775/OeC.2016.027

Polcyn, J.; Stępień, S. \& Czyżewski, B. (2019). The Measurement of the Quality of the Environment and its Determinants in Poland and in the Regional Perspective. Annales Universitatis Apulensis Series Oeconomica , 21(2): 11-21. http://doi.org/10.29302/oeconomica.2019.21.2.1

Rodriguez-Fernandez, M. (2016). Social responsibility and financial performance. The role of good corporate governance. BRQ Business Research Quarterly, 19, 137-151. http://doi.org/10.1016/j.brq.2015.08.001

Rowley, T. \& Berman, S. (2000). A brand new brand of corporate social performance. Business \& Society, 39(4), 397-418. http://doi.org/10.1177/000765030003900404 Schmidt, F.L. \& Hunter, J.E. (2014). Methods of Me- 
ta-Analysis - Correcting Error and Bias in Research Findings. $3^{\text {rd }}$ Edition, London, UK: SAGE.

Schüz, M. (2012). Sustainable Corporate Responsibility - The Foundation of Successful Business in the New Millennium. Central European Business Review, 1(2), 7-15.

Sroka, W. \& Lörinczy, M. (2015). The perception of ethics in business: Analysis of research results. Procedia Economics and Finance, 34, 156-163. http://doi. org/10.1016/S2212-5671(15)01614-7

Sroka, W. \& Szántó, R. (2018). Corporate Social Responsibility and Business Ethics in Controversial Sectors: Analysis of Research Results. Journal of Entrepreneurship, Management and Innovation, 14, 111-126. http://doi.org/10.7341/20181435

Šebestová, J.; Krejčí, P. \& Šiška, P. (2018). „Be or Not to Be": A Dilemma of Business Policy Support on a Regional Level. Central European Business Review, 7(1), 3-13. http://doi.org/10.18267/j.cebr.192

Szanto, R. (2018). The Online Communication of Corporate Social Responsibility in Subsidiaries of Multinational Companies in Hungary. Organizacija, 51(3): 160-168. http://doi.org/10.2478/orga-2018-0017

Ting, I.W.K.; Azizan, N.A.; Bhaskaran, R. et al. (2019). Corporate Social Performance and Firm Performance: Comparative Study among Developed and Emerging Market Firms. Sustainability, 2019, 12, 26. http://doi. org/10.3390/su12010026

Van Tulder, R., May Seitanidi, M., Crane, A. \& Brammer, S. (2016). Enhancing the Impact of Cross-Sector Partnerships. Four Impact Loops for Channeling Partnership Studies. Journal of Business Ethics, 135, 1-17. http://doi.org/10.1007/s10551-015-2756-4

Van Tulder, R. \& Keen, N. (2018). Capturing Collaborative Challenges: Designing Complexity-Sensitive Theories of Change for Cross-Sector Partnerships. Journal of Business Ethics, 150, 315-332. http://doi.org/10.1007/ s10551-018-3857-7

Vourvachis, P. \& Woodward, T. (2015). Content analysis in social and environmental reporting research: Trends and challenges. Journal of Applied Accounting Research, 16(2): 166-195. http://doi.org/10.1108/JAAR04-2013-0027

Vveinhardt, J. \& Sroka, W. (2020). Nepotism and Favouritism in Polish and Lithuanian Organizations: The Context of Organisational Microclimate. Sustainability, 12(4), 1425. http://doi.org/10.3390/su12041425

Vveinhardt, J.; Stonkute, E. \& Sroka, W. (2019). Discourse on Corporate Social Responsibility in the external communication of agricultural enterprises. European Journal of International Management, 13(6), 846-879. http://doi.org/10.1504/EJIM.2019.102816

Yin, R.K. (2008). Study Research. Design Methods. $4^{\text {th }}$ Edition. Thousand Oaks: Sage.
Robert Kenyon MacGregor, (MBA - Orcid ID 00000003-2888-3880, WoS Researcher ID E-9858-2019, h-index: 4, Scopus ID: 57213174280), is an academic lecturer at the International Business Department of the Metropolitan University Prague. He attended the University of Michigan, the University of California-Santa Barbara and Eastern Michigan University, with an MBA from the latter, was a sports writer with nearly 100 magazine articles published and a Realtor and Real Estate law expert. He is a common law expert and writer with a wide experience regarding management, international trade, business ethics, sustainability and USA-EU relationships. His current research interests include corporate social responsibility, financial reporting and industrial property.

Włodzimierz Sroka (Orcid ID 0000-0002-8701-0716, Researcher ID 1-1805-2013, h-index: 8, Scopus ID: 54793625000 ), is an associate professor at the Management Department of WSB University, Dąbrowa Górnicza (Poland) and specialises in theoretical and practical issues relating to management and strategic management. He is the author of numerous scientific papers on strategic alliances, network organisations, strategy, the restructuring of companies, CSR and business ethics, marketing and customer's behaviour, public management as well as innovations and entrepreneurship published in peer-reviewed international journals. He is also a member of the scientific councils of several journals (e.g. Editor in Chief at Forum Scientiae Oeconomia and Deputy Editor in Chief of the European Journal of International Management) and conferences organised by different European universities. He holds PhD, M.Sc. and B.Sc. degrees in management and marketing from the Karol Adamiecki University of Economics in Katowice, as well as a D.Sc. degree (habilitation) from the University of Žilina (Slovakia). Currently he combines his scientific activity with the position of CEO of a medium-size engineering company. He was previously employed in different managerial positions in both the steel and machine industries. 
Radka MacGregor Pelikánová, Ph.D., LL.M., MBA (Orcid 0000-0001-9628-7146, Researcher ID: G-26012018, WoS ID V-5469-2019, h-index: 8, Scopus ID: 56021587200), is an academic lecturer and researcher in the International Business Department of the Metropolitan University Prague. She graduated from Charles University Prague, Czech Republic (Ph.D. - Private Law), from the Université Paris XIII - Villetaneuse, France (Licence en Droit - Law), from Wayne State University, USA (LL.M. - Corporate and Financial Law) and National American University, USA (MBA). She is a member of both the Czech and Michigan Bar Associations and has over twenty years of lawyer, business management and academic experience. She has a prolific publishing history including seven monographs and over one hundred articles, almost half of which are classified in the WoS and Scopus database. Her current research interests include intellectual property, competition and corporate social responsibility. 